\title{
EFFECT OF GAME FORMAT ON THE INTENSITY OF SOCCER TRAINING
}

EFEITO DO FORMATO DOS JOGOS SOBRE A INTENSIDADE DO TREINAMENTO DE FUTEBOL

EFECTO DEL FORMATO DE LOS JUEGOS SOBRE LA INTENSIDAD DEL

ENTRENAMIENTO DE FÚTBOL
Felipe Lovaglio Belozo'

(Physical Education Professional)

Eliel Calazans Ferreira'

(Physical Education Professional)

Guilherme Vinicius Moreira Grandim¹

(Physical Education Professional)

Cristian Javier Ramirez Lizana' (Physical Education Professional)

João Claudio Pereira Machado² (Physical Education Professional) Vagner Ramon Rodrigues Silva' (Physical Education Professional)

Alcides José Scaglia

(Physical Education Professional)

1. Faculdade de Ciências Aplicadas, (UNICAMP), Limeira, SP, Brazil.

2. Universidade Federal do

Amazonas, (UFAM), Manaus, AM, Brazil.

\section{Correspondence:}

Felipe Lovaglio Belozo. Rua Yollanda de Dona de Vasconcelos, 339,

Sumaré, São Paulo, SP, Brazil. 13172600.flbelozo@yahoo.com

\begin{abstract}
Introduction: During training in games, it is essential to know how to correctly manipulate the formats of the games (size of field and number of players). Objective: The aim of this study was to evaluate the influence of three different game formats on the kinematic variables of training in soccer players. Methods: For this purpose, eleven U-20 soccer players participated in three games formats, Gr+3vs3+Gr, Gr+6vs6+Gr and $\mathrm{Gr}+10 \mathrm{vs} 10+\mathrm{Gr}$ in two conditions (experimental and conceptual). Through videogametry, it was possible to determine the range of speeds covered by the players during the games and to correlate with the ventilatory threshold (VT) evaluation individually to establish four different intensity zones (low intensity, moderate intensity, moderate/ high intensity or high intensity). Results: It was verified that in the experimental games, when increasing the size of the field there were significant increases in the intensity of the game. In the conceptual games, there were only significant increases of the field $\mathrm{Gr}+10 \mathrm{vs} 10+\mathrm{Gr}$ for the games $\mathrm{Gr}+6 \mathrm{vs} 6+\mathrm{Gr}$ and $\mathrm{Gr}+3 \mathrm{vs} 3+\mathrm{Gr}$. Conclusion: It is concluded that the format of the games has a significant effect on the movement of players. Level of Evidence III; Case-control study.
\end{abstract}

Keywords: Physiology; Sports; Exercise training.

\section{RESUMO}

Introdução: Durante os treinamentos em jogos, é fundamental saber manipular corretamente os formatos dos jogos (dimensão do campo e número de jogadores). Objetivo: O objetivo do estudo foi avaliar a influência de três diferentes formatos de jogo sobre as variáveis cinemáticas do treino em jogadores de futebol. Métodos: Para tanto, onze jogadores de futebol da categoria sub 20 participaram de três formatos de jogos Gr+3vs3+Gr, Gr+6vs6+Gre Gr+10vs 10+Gr em duas condições (experimental e conceitual). Por meio da videogametria, foi possivel conhecer as faixas de velocidades que os atletas percorreram durante os jogos e ao correlacionar com a avaliação de limiar ventilatório (LV), estabelecer individualmente quatro diferentes zonas de intensidade (baixa intensidade, intensidade moderada, moderada/alta ou alta intensidade). Resultados: Constatou-se que nos jogos experimentais, ao aumentar a dimensão do campo ocorreram aumentos significativos da intensidade do jogo. Nos jogos conceituais, houve apenas aumentos significativos do campo Gr+10vs 10+Gr para os jogos Gr+6vs6+Gr e Gr+3vs3+Gr. Conclusão: Conclui-se que o formato dos jogos tem efeito significativo sobre a movimentação dos jogadores. Nível de Evidência III; Estudo de caso-controle.

Descritores: Fisiologia; Esportes; Treinamento físico.

\section{RESUMEN}

Introducción: Durante los entrenamientos en juegos, es fundamental saber manejar correctamente los formatos de los juegos (tamaño del campo y el número de jugadores). Objetivo: El objetivo del estudio fue evaluar la influencia de tres diferentes formatos de juego sobre las variables cinemáticas del entrenamiento en jugadores de fútbol. Métodos: Para ello, once jugadores de fútbol de la categoría sub 20 participaron en tres formatos de juegos Gr+3vs3+Gr, Gr+6vs6+Gr y Gr+10vs $10+$ Gr en dos condiciones (experimental y conceptual). A través de videogametria, fue posible conocer las bandas de velocidad que los atletas recorrieron durante los partidos y al correlacionarlas con la evaluación del umbral de ventilatorio (UV), establecer de forma individual cuatro diferentes zonas de intensidad (baja intensidad, intensidad moderada, moderada/alta o alta intensidad). Se encontró que en los juegos experimentales, al aumentar la dimensión del campo ocurrieron aumentos sustanciales de la intensidad del juego. En los juegos conceptuales, solo hubo aumentos significativos del campo Gr+10vs 10+Gr en relación a los juegos Gr+6vs6+Gr y Gr+3vs3+Gr. Conclusión: Se concluye que el formato de los juegos tiene un efecto significativo sobre el movimiento de los jugadores. Nivel de Evidencia III; Estudio de caso-control.

Descriptores: Fisiología; Deportes; Ejercicio de entrenamiento. 


\section{INTRODUCTION}

Over the past few years, studies of small-sided games (SSGs) in soccer and other collective sports games have increased considerably. Once SSGs respect the specificity of training, they are able to improve technical, tactical, and physical aspects of training in an integrated approach. ${ }^{1-3}$

Technical and scientific development applied to soccer allowed for the elaboration of training and evaluations that take into account the principle of specificity of each game. ${ }^{4-6}$ Currently, coaches and physical trainers use games (formal and SSG) as a method to optimize training. Although most studies are focused on physical valence, ${ }^{7-9}$ recent finds show the relevance of improvement of technical and tactical abilities of players. ${ }^{10-12}$

When using games for training, it is extremely important to correctly manipulate the format of games (size of field, rules, and number of players) since these parameters seem to influence physical, technical, and tactical aspects of training. ${ }^{1,713}$ Casamichana and Castellano ${ }^{14}$ have demonstrated the importance of the size of field and individual play area in the heart rate $(\mathrm{HR})$ response, subjective perception of effort, and players'movement during games. The dimension of field alone does not cause change in heart rate since it must be associated with adjustment of the number of players in each game..$^{15}$ In their study, Kelly and Drust ${ }^{15}$ evaluated the influence of field dimension on heart rate, keeping the number of athletes in distinct games. They did not find significant differences in the HR of the players in different game formats.

It is also important to determine if the stimuli provided in the small games is sufficient to generate physical, physiological, technical, and tactical adaptations necessary in an official game, in which the size of the field, the number of players, and the total duration of the match will be higher than in the SSG training. Coelho et al. ${ }^{16}$ estimated the intensity of effort (IE) through the HR of players in friendly games, official games, and SSGs. The authors concluded that SSGs provided IE similar to that of official games, thus supporting its use in aerobic training of athletes. Despite these finds, Casamichana, Castellano, and Castagna ${ }^{17}$ emphasized the necessity of training on official fields, once they found a significant increase in the number of accelerations, number of sprints, and speeds achieved during friendly games (on official fields) in comparison to smalI-sided games. Training, therefore, should combine small, medium, and large field games, as well as friendly and official games. Unfortunately, only few studies have evaluated games performed on official fields. ${ }^{12,16}$

According to Scaglia et al., ${ }^{18}$ there are four large matrices of games: conceptual games; conceptual games in specific environments; specific games and contextual games. The objective of this study was to evaluate the effect of three different game formats $\mathrm{Gr}+3 \mathrm{vs} 3+\mathrm{Gr}$ goalkeepers ( $\mathrm{Gr}$ ) (small-sided games); $\mathrm{Gr}+6 \mathrm{vs6+Gr}$ (medium-sided games); and Gr+10vs10+Gr (large-sided games) — on the movement of young soccer players in two conditions (conceptual and experimental). In conceptual games, the structural references (balls, targets, and field dimensions) and functional references (operational principles and rules of action) did not respect the logic of official sports games. In conceptual games in a specific environment (experimental), the structural references obey those of a formal soccer game.

\section{MATERIALS AND METHODS}

Eleven junior soccer players of the U-20 category (age 18 \pm 1.2 , body mass (kg) $66.58 \pm 7.75$, height $174.04 \pm 6.93$ and fat mass (\%) of $10.90 \pm 2.90$ ) belonging to a federated Club in São Paulo, Brazil, all with a minimum of five years of experience in the sport, accepted to participate in the study. We measure the body mass (BM) and height (HT) using a digital scale equipped with stadiometer (Welmi ${ }^{\oplus}$ ). To calculate the percentage of fat ( $\% \mathrm{G}$ ), we used the Jackson and Pollock protocol. ${ }^{19}$ This study was approved by the Research Ethics Committee of the School of Medical Sciences of UNICAMP, on February 11, 2012 (Opinion No. 208.298 and CAAE: 10855212.2.0000.5404) and after all patients signed the informed consent form.

We determined the ventilatory threshold using an incremental treadmill test proposed by Lourenço et al., ${ }^{20}$ in which, at the beginning of the test, the athletes performed a three-minute warm-up running at $8-8.5 \mathrm{~km} / \mathrm{h}$ on the treadmill (Inbrasport ATL, 2000). The initial speed was $9 \mathrm{~km} / \mathrm{h}$ and slope of 1\%. The increase was $0.3 \mathrm{~km} / \mathrm{h}$ every 25 seconds. The test was performed until voluntary exhaustion, during which it was continuously monitored the variables: heart rate (Polar RS100), oxygen consumption (VO2), carbon dioxide production (VCO2) and respiratory exchange ratio (RER). We measured the cardiorespiratory parameters (VO2, VCO2 and RER) by breath through a gas analyzer (CPX/D Med Graphics, St. Paul, MN).

Therefore, we collected the variables ventilatory threshold (VT), velocity of the ventilatory threshold (VT), heart rate of the ventilatory threshold (HRvt), VO2max, velocity of VO2max (VVO2max), VO2max heart rate (VO2maxHR). These variables allowed us to establish four stratified trainings: I) low intensity- below the threshold, II) moderate intensity- between VT1 and peak respiratory compensation (PRC), III) moderate/high- between PRC and ventilatory threshold2 and IV) high intensity - above the ventilatory threshold2 (VT2).

We recorded the footage of the games with digital video cameras, with the NTSC standard and $30 \mathrm{~Hz}$ of acquisition rate. The cameras were positioned on the highest point of the bleachers, in a fixed position during the entire game, in order to fit the entire playing field.

The study of the movement of the soccer players was carried out independent of the size of the body or rotational movements hence it is important that the description of the position of the player is made from the location of a single point. ${ }^{21}$ Obtaining the position of the player on the field consists primarily in knowing the relationship between the screen coordinates $(x, y)$ and the reference system associated with the field. Thus, the calibration of each camera was made from at least four known points in the coordinate system associated with the field and their corresponding coordinates in the image. The calibration and two-dimensional (2D) reconstruction method used was proposed by Abdel-Aziz, Karara, ${ }^{22}$ named DLT (Direct Linear Transformation).

Through this screening, it was obtained the physical variables: total distance covered, maximum velocities and partial distance, divided into velocity ranges according to the assessment of $\mathrm{VT}$.

For the analysis of the games, we adopted two fields: control and experimental, with different sizes and number of players. The games configuration used are described in Table 1. The experimental games (EG) were carried out without external rules, only with the FIFA ones, including the offside rule; in the conceptual games (CG), some external rules were inserted to facilitate the tactical principle of maintaining the ball possession, according to Lizana et al..23 They are:

- Only two touches on the ball, and every extra touch means a point to the opponent;

- Taking the ball from one sideline to the other one means one point;

- Exchanging five passes in the offensive field (after the midfield) means two points;

- Goal (only allowed after the exchange of five passes) means eight points.

Table 1. Games' configuration

\begin{tabular}{c|c|c|c}
\hline \multicolumn{4}{|c}{ Configuration } \\
\hline & $\mathbf{G k + 3 v s 3 + G k}$ & $\mathbf{G k + 6 v s 6 + G k}$ & $\mathbf{G k + 1 0 v s 1 0 + G k}$ \\
\hline Size & $27 \times 18 \mathrm{~m}$ & $32 \times 52 \mathrm{~m}$ & $105 \times 64 \mathrm{~m}$ \\
\hline Total Area & $486 \mathrm{~m} 2$ & $1664 \mathrm{~m} 2$ & $6720 \mathrm{~m} 2$ \\
\hline Area per player & $61 \mathrm{~m} 2$ & $119 \mathrm{~m} 2$ & $305 \mathrm{~m} 2$ \\
\hline Goal & Official & Official & Official \\
\hline Time of game & $30 \mathrm{~min}$ & $30 \mathrm{~min}$ & $30 \mathrm{~min}$ \\
\hline GK: indicates the presence of goalkeepers in both teams.
\end{tabular}




\section{Statistical analysis}

We used Matlab 7.0 system for the elaboration of the functions related to the physical variables, such as total distance covered, maximum velocities, intervals between high intensity efforts, amount of high intensity efforts and distances covered at different velocity ranges according to the assessment of the VT of the athletes. The values were expressed as mean and standard deviation. The distribution of the data normality was verified by the Shapiro-Wilk test. After confirming that the data was parametric, we used ANOVA for repeated measurements to compare different games' configuration in specific conditions. The value of $p<0.05$ was considered statistically significant.

\section{RESULTS}

We observed a significant increase in distances covered by athletes in different speed ranges and also in the physical variables studied. It is important to note that in CG (with external rules), there is a significant difference in movement of players only in the field $G k+10 v s 10+G k$ when compared to Gk+6vs6+Gkand Gk+3vs3+Gkfields. The results of distances covered in different speed ranges are shown in Table 2.

In Table 3, we show the results of the physical variables (distance in high intensity, interval between high-intensity actions, maximum speed, quantity of actions in high intensity, and total distance covered) in different games' configuration. It is important to note that for $C G$, no variable showed significant differences between formats $G k+3 v s 3+G k$ and $G k+6 v s 6+G k$.

In $E G$, we observed a significant increase of general movement of players in the configuration $G k+6 v s 6+G k$, when compared to the Gk+3vs3+Gk configuration. There were also significant differences in $\mathrm{EG}$ and $\mathrm{CG}$, between the $\mathrm{Gk}+10 \mathrm{vs} 10+\mathrm{Gk}$ configuration and the others $(G k+3 v s 3+G k$ and $G k+6 v s 6+G k)$ in moderate, moderate/high, and high intensities. There were no significant differences in distances covered below the threshold (low intensity) between these three field configurations.

\section{DISCUSSION}

The main objective of this study was to evaluate the effect of different games' configuration (field size and number of players) in two conditions (experimental and conceptual) and in velocity ranges according to individual ventilator threshold (VT), and in other physical variables: maximum speed, interval between high-intensity actions, quantity of actions at high intensity, and total distance covered. According to our results, our first conclusion is that in EG (FIFA rules only) the bigger the field size and number of players, the greater the physical responses between the formats and the distances covered in different speed ranges. These significant differences are due to the larger physical space, where it is possible to travel greater distances and reach higher speeds. ${ }^{1,8,9,12}$

Castelano et al. ${ }^{7}$ point out that without direct contact with the ball on the feet, great physical space to cover, and a small number of opponents, it is easier to reach the maximum speed and to cover greater distances at high intensities, which usually occurs on an official field. We found that the number of actions in high intensity and the distances covered in moderate, moderate/high, and high intensities were significantly higher in larger dimensions. Our data corroborate Hill-Hass et al., ${ }^{8}$ who also found a significant increase in distances covered in high intensity on fields with larger dimensions. Besides the size of the field, the movement of the athletes, and the number of players, the control of the physiological responses of each athlete is also of fundamental importance during training through experimental games.

Although the bigger the size of the field and the number of players, the greater the distances traveled in high intensity and the maximum speeds reached, some studies emphasize that the physiological intensity is significantly superior in the small games in relation to the medium and large ones. ${ }^{7,12,24,25}$ According to Jones and Drust, ${ }^{11}$ with fewer player, athletes need to move more across the field in order to receive the ball or to perform offensive and defensive actions. Castelano et al. ${ }^{7}$ confirm that the physiological intensity of the big games is smaller than in small games, since the greater the number of players on the field, the less individual contact with the ball; the offensive and defensive actions are also more sectorized.

Our second finding diverges from the literature. While many works on conceptual games demonstrate a significant increase in the movement of players in larger field dimensions, ${ }^{1,7,26}$ we did not find significant differences between $\mathrm{Gk}+3 \mathrm{vs} 3+\mathrm{Gk}$ and $\mathrm{Gk}+6 \mathrm{vs} 6+\mathrm{Gk}$ in variables analyzed. We only find significant differences between $\mathrm{Gk}+10 \mathrm{vs} 10+\mathrm{Gk}$ and the other two (Gk+3vs3+Gk and Gk+6vs6+Gk), due to the large increase in the

Table 2. Mean and standard deviation of the intensities of players' movements in different configuration and game conditions.

\begin{tabular}{|c|c|c|c|c|c|c|}
\hline & \multicolumn{3}{|c|}{ Experimental games (EG) } & \multicolumn{3}{|c|}{ Conceptual games (CG) } \\
\hline & $G k+3 v s 3+G k$ & $\mathrm{Gk}+6 \mathrm{vs} 6+\mathrm{Gk}$ & Gk+10vs $10+G k$ & $\mathrm{Gk}+3 \mathrm{vs3}+\mathrm{Gk}$ & $\mathrm{Gk}+6 \mathrm{vs} 6+\mathrm{Gk}$ & Gk+10vs10+Gk \\
\hline $\begin{array}{l}\text { Below threshold (m) } \\
\text { Low intensity }\end{array}$ & $2185,5 \pm 170,2$ & $2199,8 \pm 194,3$ & $2182,9 \pm 184,1$ & $2212,0 \pm 208,4$ & $2274,3 \pm 194,8$ & $2313,3 \pm 216,3$ \\
\hline $\begin{array}{c}\text { Between threshold and PCR }(\mathrm{m}) \\
\text { Moderate intensity }\end{array}$ & $219,93 \pm 93,9 b, c$ & $257,42 \pm 131,3^{a, c}$ & $399,72 \pm 250,2^{a, b}$ & $253,5 \pm 104,7^{f}$ & $264,02 \pm 139,9^{f}$ & $360,14 \pm 189,5^{d, e}$ \\
\hline $\begin{array}{c}\text { Between PCR and VO2max (m) } \\
\text { Moderate/high intensity }\end{array}$ & $227,71 \pm 83,7^{b, c}$ & $290,09 \pm 65,6^{a, c}$ & $435,69 \pm 98,6^{a, b}$ & $233,85 \pm 101,7^{f}$ & $259,38 \pm 88,4^{f}$ & $398,32 \pm 93,0^{d, e}$ \\
\hline $\begin{array}{l}\text { Above VO2max (m) } \\
\text { High intensity }\end{array}$ & $139,71 \pm 49,3^{b, c}$ & $360,89 \pm 155,7^{a, c}$ & $579,89 \pm 173,9^{a, b}$ & $107,66 \pm 58,7^{f}$ & $180,06 \pm 65,4^{f}$ & $393,40 \pm 119,3^{d, e}$ \\
\hline
\end{tabular}

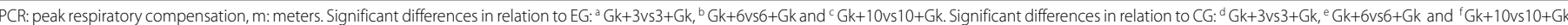
Level of significance: $p<0.05$.

Table 3. Mean and standard deviation of the movement characteristics in different configuration and game conditions.

\begin{tabular}{|c|c|c|c|c|c|c|}
\hline & \multicolumn{3}{|c|}{ Experimental games (EG) } & \multicolumn{3}{|c|}{ Conceptual games (CG) } \\
\hline & $\mathrm{Gk}+3 \mathrm{vs} 3+\mathrm{Gk}$ & $\mathrm{Gk}+6 \mathrm{vs} 6+\mathrm{Gk}$ & Gk+10vs10+Gk & Gk+3vs3+Gk & Gk+6vs6+Gk & Gk+10vs10+Gk \\
\hline Dist. High Intensity (m) & $8,52 \pm 1,26^{b, c}$ & $10,78 \pm 1,15^{a, c}$ & $14,8 \pm 1,71 a, b$ & $8,31 \pm 0,92$ & $9,49 \pm 1,02$ & $11,87 \pm 1,56$ \\
\hline Interval between High Intensity Actions(s) & $61,9 \pm 23,1^{b, c}$ & $41,7 \pm 17,0^{\mathrm{a}, \mathrm{c}}$ & $29,02 \pm 9,5^{a, b}$ & $72,3 \pm 20,1^{f}$ & $54,8 \pm 18,8^{f}$ & $32,8 \pm 8,0^{e, d}$ \\
\hline Maximal speed (m/s) & $7,1 \pm 0,4^{b, c}$ & $8,2 \pm 0,76^{a}$ & $9,3 \pm 0,89^{a}$ & $6,4 \pm 0,38^{f}$ & $6,9 \pm 0,65^{f}$ & $8,6 \pm 0,97^{e, d}$ \\
\hline Quantity of High Intensity Actions (n) & $29,27 \pm 9,4^{b, c}$ & $45,82 \pm 18,5^{a, c}$ & $57,27 \pm 15,9^{a, b}$ & $23,4 \pm 10,4^{f}$ & $31,8 \pm 9,3^{f}$ & $50,0 \pm 10,8^{e, d}$ \\
\hline Total distance covered (m) & $2772,94 \pm 158,3^{\mathrm{b}, \mathrm{c}}$ & $3108,29 \pm 112,9 a, c$ & $3598,29 \pm 281,2^{a, b}$ & $2087,0,9 \pm 205,8^{f}$ & $2977,77 \pm 252,7^{f}$ & $3463,14 \pm 287,8^{\mathrm{e}, \mathrm{c}}$ \\
\hline
\end{tabular}

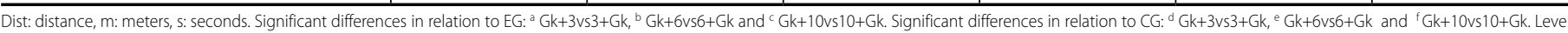
of significance: $p<0.05$. 
physical dimension of the field and consequently in the individual area per player ( $\mathrm{m}^{2} /$ player). It is important to emphasize that, differently from the studies cited above, we introduced some external rules imposed by the technical commission, which intensified efforts in favor of the operational principle of maintenance of ball possession. These rules, although they should be used in training through conceptual games, ${ }^{18}$ can influence the movement of players, according to a previous study ${ }^{27}$ and may explain our results.

Da Mota et al. ${ }^{28}$ found that teams with greater possession of the ball cover smaller total distance. Therefore, it is important to emphasize that besides the rules, the team's game model and the configuration of the games directly influence the movement of players during training

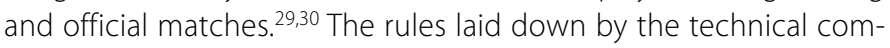
mission should not be drawn merely to obtain the physical results, but also in the development of technical aspects and operational or tactical principles. ${ }^{23}$ They must be designed according to the game model desired by the coach.

\section{CONCLUSION}

Taking into account what has been mentioned, we conclude that different games' configuration influence the physical variables and the movement of the athletes during training through games. Thus, training through games in different field dimensions (small, medium, and large) and in different matrices (conceptual games, conceptual in a specific environment, specific, and contextual) is important. A limitation of the present study was the absence of physiological response data of athletes during the games, however it is indispensable the individual monitoring of athletes during the training sessions, once studies indicate that the small games provide the greatest physiological demands. Knowing the athletes is fundamental to elaborate the periodization of training and to insert the games in the sessions of training according to the period of preparation of the team.

All authors declare no potential conflict of interest related to this article.

AUTHORS' CONTRIBUTIONS: Each author made significant individual contributions to this manuscript. FLB (0000-0002-4478-2177)*: contributed to the data collection and writing of the article; ECF (0000-0001-6964-8284)*: data collection, revision of the article and writing of the discussion of data; GVMG (0000-0002-8565-4913)*: data collection and revision of the article; CJRL (0000-0002-8608-8060)* data collection, writing of the discussion and revision of the article; JCPM (0000-0001-9827-5296)* and VRRS (00000003-4793-1075)*: statistical analyses and writing of results; AJS (0000-0003-1462-1783)* advisor of the article, revision of the article and intellectual content of the article. *ORCID (Open Researcher and Contributor ID).

\section{REFERÊNCIAS}

1. Hill-Haas SV, Dawson B, Impellizzeri FM, Coutts AJ. Physiology of small-sided games training in football: a systematic review. Sports Med. 2011;41(3):199-220.

2. Impellizzeri FM, Marcora SM, Castagna C, Reilly T, Sassi A, laia FM, et al. Physiological and performance effects of generic versus specific aerobic training in soccer players. Int J Sports Med. 2006;27(6):483-92.

3. Reilly T. An ergonomics model of the soccer training process. J Sports Sci. 2005;23(6):561-72.

4. Hoff J, Wisløff U, Engen LC, Kemi OJ, Helgerud J. Soccer specific aerobic endurance training. Br J Sports Med. 2002;36(3):218-21.

5. Kelly DM, Gregson W, Reilly T, Drust B. The development of a soccer-specific training drill for elite-level players. J Strength Cond Res. 2013;27(4):938-43.

6. Lizana CJR, Belozo FL, Lourenço T, Brenzikofer R, Macedo DV, Misuta MS, et al. Análise da potência aeróbia de futebolistas por meio de teste de campo e teste laboratorial. Rev Bras Med Esporte. 2014;20(6):447-50.

7. Castellano J, Casamichana D, Dellal A. Influence of game format and number of players on heart rate responses and physical demands in small-sided soccer games. J Strength Cond Res. 2013;27(5):1295-303.

8. Hill-Haas SV, Dawson BT, Coutts AJ, Rowsell GJ. Physiological responses and time-motion characteristics of various small-sided soccer games in youth players. J Sports Sci. 2009;27(1):1-8.

9. Aguiar MV, Botelho GM, Goncalves BS, Sampaio JE. Physiological responses and activity profiles of football small-sided games. J Strength Cond Res. 2013;27(5):1287-94.

10. Casamichana D, Suarez-Arrones L, Castellano J, Roman-Quintana JS. Effect of number of touches and exercise duration on the kinematic profile and heart rate response during small-sided games in soccer. J Human kinet. 2014;41:113-23.

11. Jones S, Drust B. Physiological and techinical demands of $4 \mathrm{v} 4$ and $8 \mathrm{v} 8$ games in elite youth soccer players. Kinesiology. 2007;39(2):150-6.

12. Owen AL, Wong DP, Poul D, Dellal A. Physical and technical comparisons between various-sided games within professional soccer. Intern J Sports Med. 2014;35:286-92.

13. Hodgson C, Akenhead R, Thomas K. Time-motion analysis of acceleration demands of $4 \mathrm{v} 4 \mathrm{small}$-sided soccer games played on different pitch sizes. Hum Mov Sci. 2014;33:25-32.

14. Casamichana D, Castellano J. Time-motion, heart rate, perceptual and motor behaviour demands in small-sides soccer games: effects of pitch size. J Sports Sci. 2010;28(14):1615-23.

15. Kelly DM, Drust B. The effect of pitch dimensions on heart rate responses and technical demands of small-sided soccer games in elite players. J Sci Med Sport. 2009;12(4):475-9.

16. Coelho DB, Rodrigues VM, Condessa LA, Mortimer LACF, Soares DD, Silami-Garcia E. Intensidade de sessões de treinamento e jogos oficiais de futebol. Rev Bras Educ Fís Esp. 2008;22(3):211-18

17. Casamichana D, Castellano J, Castagna C. Comparing the physical demands of friendly matches and small-sided games in semi-professional soccer players. J Strength Cond Res. 2012;26(3):837-43.

18. Scaglia AJ, Reverdito RS, Leonardo L, Lizana CJR. O ensino dos jogos esportivos coletivos: as competências essenciais e a lógica do jogo em meio ao processo organizacional sistêmico. Movimento. 2013;19(4):227-49.

19. Jackson AS, Pollock ML. Generalized equations for predicting body density of men. Br J Nutr 1978;40(03):497-504.

20. Lourenco TF, Martins LE, Tessutti LS, Brenzikofer R, Macedo DV. Reproducibility of an incremental treadmill VO(2)max test with gas exchange analysis for runners. J Strength Cond Res. 2011;25(7):1994-9.

21. Misuta MS, Menezes RP, Figueroa PJ, Cunha SA, Barros RML. Análise de distâncias percorridas e velocidades de jogadores de futebol durante uma partida. João Pessoa, PB. 2005

22. Abdel-Aziz YI, Karara HM. Direct linear transformation from comparator coordinates into object-space coordinates in close-rang photogrammetry. Synposium Onclosee-Rane Photogrammetrry. Urbana: ASP/Ul; 1971. p. 1-18.

23. Lizana CJR. Reverdito RS, Brenzikofer R, Macedo DV, Misuta MS, Scaglia AJ. Technical and tactical soccer players' performance in conceptual small-sided games. Motriz. 2015;21(3):312-20.

24. Aguiar M, Botelho G, Lago C, Macas V, Sampaio J. A review on the effects of soccer small-sided games. J Human kinet. 2012;33:103-13.

25. Harrison CB, Gill ND, Kinugasa T, Kilding AE. Quantification of physiological, movement, and technical outputs during a novel small-sided game in young team sport athletes. J Strength Cond Res. 2013;27(10):2861-8.

26. Hill-Haas SV, Coutts AJ, Dawson BT, Rowsell GJ. Time-motion characteristics and physiological responses of small-sided games in elite youth players: the influence of player number and rule changes. I Strength Cond Res. 2010;24(8):2149-56

27. Belozo FL, Ferreira EC, Lizana CJR, Grandim G, Machado JC, Brenzikofer R, et al. The effect of the maintaining the ball possession on the intensity of games. Motriz. 2016;22(1):65-72.

28. da Mota GR, Thiengo CR, Gimenes SV, Bradley PS. The effects of ball possession status on physical and technical indicators during the 2014 FIFA World Cup Finals. J Sports Sci. 2016;34(6):493-500.

29. Clemente FM, Couceiro MS, Martins FM, Ivanova MO, Mendes R. Activity profiles of soccer players during the 2010 world cup. J Hum Kinet. 2013;38:201-11.

30. Praça GM, Folgado H, Andrade AGP, Greco PJ. Comportamento tático coletivo em Pequenos Jogos no Futebol: influência de jogadores adicionais. Revista Brasileira de Cineantropometria \& Desempenho Humano. 2016;18:62-71. 